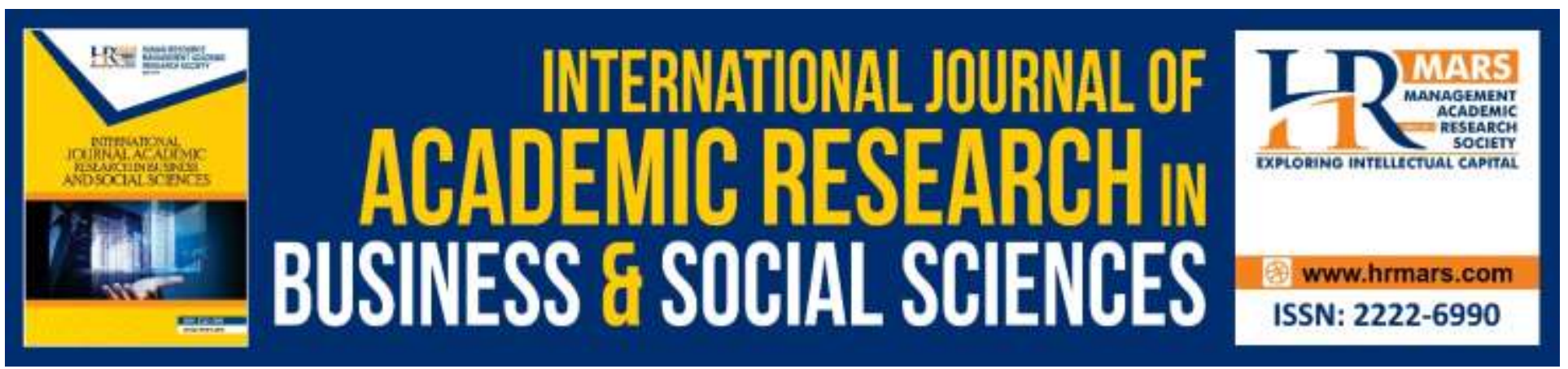

\title{
Training Practice, a Perspective of Employee Retention in Firms
}

Chumo Sylvia Chepkosgey, G. S. Namusonge, Elizabeth Nambuswa Makokha

To Link this Article: http://dx.doi.org/10.6007/IJARBSS/v9-i7/6141

DOI: $10.6007 /$ IJARBSS/v9-i7/6141

Received: 24 May 2019, Revised: 10 June 2019, Accepted: 02 July 2019

Published Online: 27 July 2019

In-Text Citation: (Chepkosgey, Namusonge, \& Makokha, 2019)

To Cite this Article: Chepkosgey, C. S., Namusonge, G. S., \& Makokha, E. N. (2019). Training Practice, a Perspective of Employee Retention in Firms. International Journal of Academic Research in Business and Social Sciences, 9(7), 495-509.

\section{Copyright: (C) 2019 The Author(s)}

Published by Human Resource Management Academic Research Society (www.hrmars.com)

This article is published under the Creative Commons Attribution (CC BY 4.0) license. Anyone may reproduce, distribute, translate and create derivative works of this article (for both commercial and non-commercial purposes), subject to full attribution to the original publication and authors. The full terms of this license may be seen

at: http://creativecommons.org/licences/by/4.0/legalcode

Vol. 9, No. 7, 2019, Pg. 495 - 509

http://hrmars.com/index.php/pages/detail/IJARBSS

JOURNAL HOMEPAGE

Full Terms \& Conditions of access and use can be found at http://hrmars.com/index.php/pages/detail/publication-ethics 


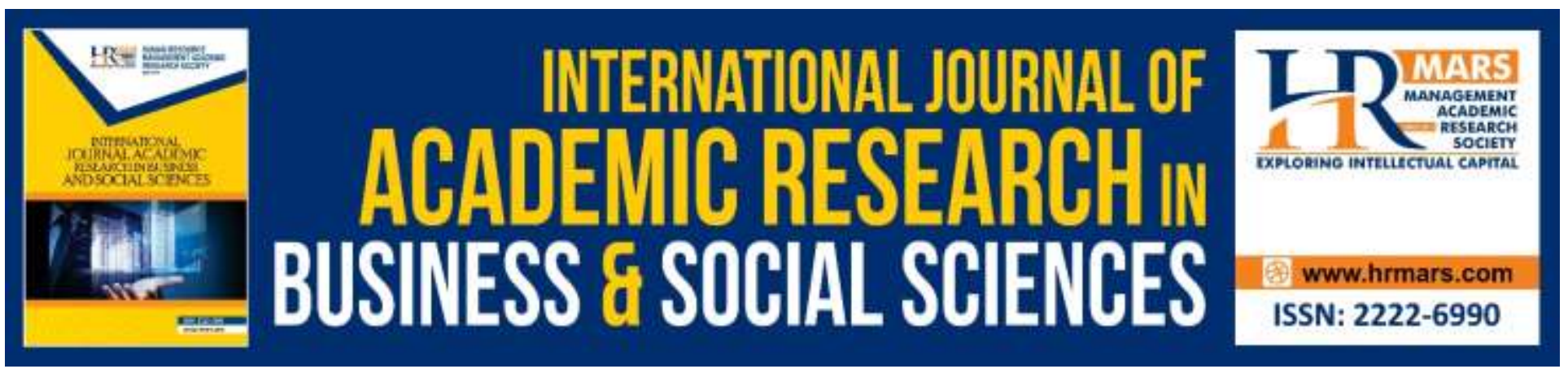

\title{
Training Practice, a Perspective of Employee Retention in Firms
}

\author{
Chumo Sylvia Chepkosgey, G. S. Namusonge, Elizabeth Nambuswa \\ Makokha \\ Jomo Kenyatta University of Agriculture and Technology, Kenya \\ School of Entrepreneurship, Procurement and Management, Nairobi, Kenya
}

\begin{abstract}
The rate of employee turnover can affect the performance of an organization and therefore employee retention is considered of utmost importance globally. Hence, this study sort to investigate the influence of training practices on performance of employees' retention in firms. The study was conducted using survey design to establish the relationship between variables. The target population was 2940 employees of beverage firms in Kenya and the sample size was 352 employees which was calculated using Taro Yamanes formula. The study adopted structured questionnaires to get answers of the research questions. Questionnaires were used to collect data and later on analysed using descriptive statistics and presented in frequency tables. It was established that training showed a positive correlation with retention of employees in beverage processing firms. The study recommended that beverage processing firms should involve employees to participate in decision making in order to allow them identify areas they need to be trained. Lastly, the study findings would be of great benefit to the beverage processing firms, academicians, researchers and policy makers.
\end{abstract}

\section{Introduction}

The rate of employee turnover affects the performance of an organization and therefore employee retention is considered of utmost importance globally (Ayodo et al. 2014). In today's competitive global market the only strategy for organizations to improve workforce productivity radically and enhance retention is to seek to optimize their workforce through comprehensive training and development programs. Low turnover ensures that organization is retaining their competent employees by providing them superior environment, which increases the performance of individual employee Ayodo et al. (2014, as cited in Hassan et. al 2013). In the face of restructuring, organizations in a bid to remain in business and still be effective in their ventures managers need to maximize on their strategic resources by carefully isolating for retention the best-trained, experienced, disciplined, 
productive and effective employees to sustain a competitive advantage and differentiate themselves from their competitors Ayodo et al. 2014).

Employee retention is a key factor in an organizations' success (Lyria, Namusonge \& Karanja, 2014). However, nowadays many organizations globally find it difficult to retention their employees and this has been occasioned by globalization mobility of highly skilled employees ( $\mathrm{Ng}^{\prime}$ ethe, Iravo \& Namusonge, 2012). Many scholars are in agreement that employees will leave companies in search of better payments packages, better career and development opportunities and job satisfaction among other factors (Shen \& Hall, 2009). Employee turnover can result in interruptions, increased replacement and recruitment costs, loss of efficiency, incomplete projects, customer dissatisfaction, scheduling difficulties and the depletion of the company's intellectual capital (Kreisman, 2002).

In United Kingdom a survey of London health service staff showed that poor working conditions and lack of better facilities were top on the list of factors affecting retention while compensation ranked fourth (Trust, 2005). In Kenya, (Messah \& Kubai, 2011) carried out a survey of factors influencing agent retention in insurance industry in Kenya and observed that basic pay, training and development, promotion ranked highest on factors that employee would consider while moving to another organization. According to Mensah (2014) he established that majority of managers consider retention of their best employees to be an important part of their long term business strategy but many organisations do not have a framework in place to effectively retain their employees. Studies reviewed in the literature indicate that retention factors vary from one industry to the other and a factor could rank high in one industry, lower or is totally irreverent. It is this diversity in retention from one organization to another that this study wanted to investigate the influence of training practice and employee retention in selected beverage processing firms in Kenya.

\section{Literature Review}

The rate of employee turnover affects the performance of an organization and therefore employee retention is considered of utmost importance globally, Ayodo et al, (2014).In today's competitive global market the only strategy for organizations to improve workforce productivity radically and enhance retention is to seek to optimize their workforce through comprehensive training and development programmes. Low turnover ensures that organization is retaining their competent employees by providing them superior environment, which increases the performance of individual employee Ayodo et al, (2014, as cited in Waleed Hassan et.al 2013). In the face of restructuring, organizations in a bid to remain in business and still be effective in their ventures managers need to maximize on their strategic resources by carefully isolating for retention the best-trained, experienced, disciplined, productive and effective employees to sustain a competitive advantage and differentiate themselves from their competitors Ayodo et al, 2014).

Training practices in organizations should be guided by polices which should be adhered to always. Training is beneficial to the organization as well to the individual. With a well trained workforce, the organization will turn out a high standard of goods or services, probably in more cost-effective manner than others, and therefore, with a better chance of achieving organizational goals are they profit oriented or service oriented. Other benefits to the organization include maintenance of a sufficient and suitable range of skills amongst employees; development of knowledge and skills in the workforce; achievement of improved job performance and productivity; improved quality; improved 
service to customers and increased motivation among employees. There are also benefits to individuals which include increase in personal repertoire of skills; increased satisfaction; increased value of employees in the labour market and improved prospects of internal promotion (Cole, 2005).Opportunities for training are among the most important reasons why employees stay especially young and enthusiastic ones. Indeed, Dockel (2003) states that investment in training is one way to show employees how important they are. One of the factors that Hertzberg identifies as an important motivator is the growth opportunities. Armstrong (2010) argues that people enjoy learning and continuous training provides for this. Therefore, training is a satisfying and rewarding experience and makes a significant contribution to intrinsic motivation. Employees want good training opportunities to increase their marketability. The conventional wisdom used to be that if the company makes them marketable, employees will leave at the first opportunity. But today, companies are finding that the more training employees get, the more likely they are to stay on. Indeed, when the training ends, turnover tends to begin (Hill, 2002 cited in Chew 2004). Tettey (2006) observes that professional development is the engine that keeps the universities true to their mandate as centers of ideas and innovation. Without efforts in this direction, intellectual capital can stagnate and the relevance of universities to society may diminish. Academic staff thrives on intellectual and collegial stimulation from their peers when they attend professional activities and national and international research meetings. Thus, development activities for faculty members continue to be an important aspect associated with their professional work lives (Rosser, 2004).

Training is important because it prevents knowledge obsolescence and plays a key role of advancing knowledge and skills of staff for them to play new roles. As universities are faced with accelerating changes in their environment, teachers need to improve their skills in the acquisition and management of new knowledge (Obwogi, 2011).Chacha (2004), staff training is one of the areas that lag behind and impacts negatively on teaching and research. Up to two thirds of university teachers have had no initial pedagogical training. Most of these institutions are relying on individuals who have not acquired their highest level of academic training as lecturers. To improve their efficiency and effectiveness in delivering their services, staff and especially the academic staff, must be trained continually in relevant areas. Universities must have a clear training policy, outlining their strategy for human resource development. Dockel (2003), states that employees stay at companies that promote career opportunities through learning, and the ability to apply their newly learned skills. Chew (2004), level of employee turnover and training are expected to be inversely related; the higher the level of training, the lower the turnover intention. This expectation is based on the reasoning that the longer an employee stays with an employer; the higher will be the return on training. Waleed (2011) argues that appropriate training contributes positively to employee retention because it makes employee feel recognized for their strengths and creates possibilities to develop their qualities.

According to previous studies several factors are considered important in retaining employees. The factors which have a direct effect on employee retention are career management adds real value to retention. Suppose if an employee learnt a lot in training session but when it comes to apply it in job, the manager or supervisor shows very little interest to support him/her, this will discourage the employee. So employee cannot take benefit of training program. And eventually this will lead to dissatisfaction of employee. Samganakkan, (2010) in his article he identified how the human resource 
management practices such as training, appraisal etc affect the employee, their intention to stay and their motivation. According to his research training is an important determinant of employee motivation and retention. He identified that compensation should be such which force the employees to stay in the organization as retention is an important matter for the organizations effectiveness. The company to become a good employer and also to succeed it is important that they keep their turnover rate low and for this purpose he identified that compensation is one of the important things to keep employees motivated and retain. Thus, the study proposed the hypothesis that: training practice has no significant influence on employee retention in firms.

On the other hand, employee retention is a process in which the employees are encouraged to remain with the organization for the maximum period of time or until the completion of the project. Retention of human resource is critically important in organizations and institutions where financial sustainability and survival in a competitive environment depend on the scarce human and specialist skills. The situation is further exacerbated if these individuals are rare or when it becomes difficult to obtain and retain these kind of staff (Phillips et.al. 2003). Organizations therefore, must continuously discover current retention factors and integrate them in the organization. Without empirical evidence, it is not known if the current organizational retention strategies are outdated as they may have little or no influence on employees' decision to stay with an organization (Sutherland, 2004).

One of the major reasons why staff retention is important is due to the numerous negative outcomes that are associated with labour turnover. These organizational outcomes include high direct and indirect financial costs; a decrease in financial sustainability, a decrease in productivity; the rendering of service and standards; interruption in workflow; loss of experience and specialist knowledge; an increase in administrative processes; a decline in the organizations image; an interruption in the internal and informal social liaison and communication channels and an increased feeling of job dissatisfaction among the remaining staff Pienaaret al., (2008).

However, various studies have identified an array of factors that influence employee retention. Chew (2004), in a study on retention of employees in Australian organizations, established that younger employees focused on remuneration, training and development, career advancement, challenging work, growth opportunities and recognition. For older employees, autonomy, opportunities to mentor and job challenge were of great importance. A study by Daly et al., (2006) on turnover intention of academics established that structural factors such as faculty work environment, autonomy, communication, distributive justice and workload were related to intent to stay. Amutuhaire (2010) in a study of academics in Makerere University established that remuneration and tenure influenced their retention. Locally, a study of staff retention in service organizations (Udi, 2010) established that lack of adequate reward and compensation and lack of career development in terms of promotion influenced employees to leave. Kipkebut (2010) in a study on organizational commitment and job satisfaction of employees in universities in Kenya established that role conflict, promotional opportunities, age were some of the factors that influenced employee intention to quit from the university and hence affected staff retention. These findings reflect a mixture of intrinsic and extrinsic factors. In terms of the effect of training on employee retention, Srinivas (2008) reveals that there is a strong association between training opportunities in organizations and sustainable employee retention. In the same vein, studies by (Boon \& Arumugam, 2006 and Bashir and Ramay (2008) corroborate with the previous proposition. These studies reveal the existence of positive and 
significant relationship between training practices and employee retention rate. Following the studies analyzed, it can be concluded that the basic trend in literature is that training and development results in high employee retention rates. Training according to chew (2004), provides employees with specific skills or correct deficiencies in their performance, while development is an effort to provide employees with abilities the organization will need in the future. Huselid (1995), providing training and job security by organization are important determinants of employees Retention. Human resource practices, such as training are positively correlated to retention, because the practice 'lock' employees in their jobs- this is called employees retention. This is in agreement with the assertion of wan (2007) that the only strategy for organization to radically improve workforce productivity and enhance their retention is to seek to optimize their workforce through comprehensive training and development. For organizations to achieve this purpose, they need to plough resources into the training of their personnel so as to be competitive in the near future. Staff that are not trained stand no chance of being promoted and so has a future that is bleak, this makes some employees look for alternative job where their trainings guaranteed. Therefore, this study adopted various constructs to measure employees' retention such as remuneration, training and development, career advancement, challenging work, growth opportunities and recognition.

\section{Research Methodology}

The study was conducted using survey design to establish the relationship between variables. The target population was 2940 employees of beverage firms in Kenya and the sample size was 352 employees which was calculated using Taro Yamanes formula. The study adopted structured questionnaires to get answers of the research questions. Questionnaires were used to collect data and later on analysed using descriptive statistics and presented in frequency tables. Piloting was conducted using Cronbach Alpha and all Coefficients were above 0.7 implied that reliability of the data collection instrument was good.

\section{Research Findings and Discussion}

The study sought to determine the influence of training practice on employee retention in beverage processing firms in Kenya. The respondents were asked to indicate the influence of training practice on employee retention in selected beverage processing firms in Kenya. This was on a scale of strongly agree, agree, undecided, disagree and strongly disagree. The score of strongly agree represented very high influence of training on employee retention and was taken to be equivalent to mean score of 4.1 to 5.0 on the likert scale. The score agree represented high influence of training on employee retention and was taken to be equivalent to a mean score of 3.1 to 4.0. The score undecided represented neutral influence of training on employee retention and was taken to be equivalent to mean score of 2.1 to 3.0. The disagree scores represented low influence of training on employee retention and was taken to be equivalent to mean score of 1.1 to 2.0 and the score strongly disagree represented influence of training on employee retention and was taken to be equivalent to mean score of 0.1 to 1.0. A standard deviation of more than one implies a significant difference in respondents. A result of the analysis is presented in Table below. 


\section{Results of Training Practice}

\begin{tabular}{|c|c|c|c|c|c|c|c|}
\hline Statements on training & $\begin{array}{l}\text { Strongly } \\
\text { disagre } \\
\text { e }(\%)\end{array}$ & $\begin{array}{l}\text { Disagre } \\
\text { e \%) }\end{array}$ & $\begin{array}{l}\text { Undecide } \\
\mathrm{d}(\%)\end{array}$ & $\begin{array}{l}\text { Agre } \\
\text { e (\%) }\end{array}$ & $\begin{array}{l}\text { Strongl } \\
\text { y agree } \\
(\%)\end{array}$ & Mean & $\begin{array}{l}\text { Std. } \\
\text { Deviation }\end{array}$ \\
\hline $\begin{array}{l}\text { 1. There is a } \\
\text { training policy } \\
\text { for our } \\
\text { company }\end{array}$ & 18 & 0 & 3.5 & 50.2 & 28.4 & $\begin{array}{l}3.709 \\
3\end{array}$ & 1.36370 \\
\hline $\begin{array}{l}\text { 2. Training } \\
\text { opportunities } \\
\text { are regular for } \\
\text { our company }\end{array}$ & 0 & 47.8 & 3.5 & 32.9 & 15.9 & $\begin{array}{l}3.169 \\
6\end{array}$ & 1.19125 \\
\hline $\begin{array}{l}\text { 3. The } \\
\text { implementatio } \\
\mathrm{n} \text { of training } \\
\text { policy is fair in } \\
\text { our company }\end{array}$ & 4.5 & 40.8 & 11.4 & 35.3 & 8 & $\begin{array}{l}3.013 \\
8\end{array}$ & 1.12414 \\
\hline $\begin{array}{l}\text { 4. The training } \\
\text { have received is } \\
\text { relevant to my } \\
\text { job }\end{array}$ & 4.5 & 21.5 & 3.5 & 37.7 & 32.9 & 3.73 & 1.249 \\
\hline $\begin{array}{l}\text { 5. I am satisfied } \\
\text { with the } \\
\text { training } \\
\text { practices }\end{array}$ & 9 & 45.3 & 3.5 & 35.3 & 6.9 & 2.86 & 1.195 \\
\hline
\end{tabular}

From the study findings above, it was established that beverage processing firms train their employees in order to equip them with relevant skills on their jobs which was rated high at 3.73 on the scale of 1 to 5. Also, it was noted that beverage processing firms have come up with training policy which was rated highly at 3.7 on the scale of 1 to 5 . It was also revealed that the implementation of training policy in beverage processing firms was done in fairly and was revealed high at 3.0 on the scale of 1 to 5. Likewise, the study indicated that training of employees in beverage processing firms was done on regular bases and thus gives firms ample time to plan for scarce resources. However, the respondents indicated that they are neither nor satisfied with the training practice conducted by beverage processing firms.

Based on the study findings, it's clearly evident that beverage processing firms train their employees, have got training policy, implementation of training policy was done fairly and training of employees was done on regular bases. These study findings corresponds with the study of Cole (2005) who established that training practices in organizations should be guided by polices which should be adhered to always. With a well trained workforce, the organization will turn out a high standard of 
goods or services, probably in more cost-effective manner than others, and therefore, with a better chance of achieving organizational goals are they profit oriented or service oriented. Other benefits to the organization include maintenance of a sufficient and suitable range of skills amongst employees; development of knowledge and skills in the workforce; achievement of improved job performance and productivity; improved quality; improved service to customers and increased motivation among employees. There are also benefits to individuals which include increase in personal repertoire of skills; increased satisfaction; increased value of employees in the labour market and improved prospects of internal promotion.

Equally, Armstrong (2010) argued that people enjoy learning and continuous training provides for this. Therefore, training is a satisfying and rewarding experience and makes a significant contribution to intrinsic motivation. Employees want good training opportunities to increase their marketability. Also, Obwogi (2011) found that training is important because it prevents knowledge obsolescence and plays a key role of advancing knowledge and skills of staff for them to play new roles. As universities are faced with accelerating changes in their environment, teachers need to improve their skills in the acquisition and management of new knowledge. In addition Universities must have a clear training policy, outlining their strategy for human resource development.

Nevertheless, the study established that some employees are not satisfied with the training practice in beverage processing firms. This maybe result of not involving employees in participating directly in the areas they want to be trained. Paulo and Anantharaman (2004) established that all-inclusive training depicts a significant and positive linkage with organizational commitment and job satisfaction.

The study also, conducted regression analysis so as to determine the influence of training practice on employee retention in selected beverage processing firms in Kenya. The hypothesis tested was: Training practice has no significant influence on employee retention in selected beverage processing firms in Kenya. The findings are indicated below.

\section{Model Summary of Training Practice}

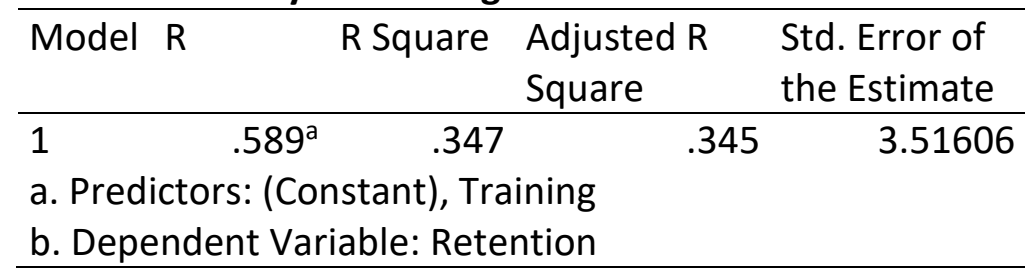

The linear regression model showed that adjusted $R^{2}=0.345$ which means that 34.5 percent change of employee retention in selected beverage processing firms in Kenya can be explained by a unit change of training practice. The result is shown in table above. Also, the result indicated that one unit change in training translates to $\mathbf{4 5 . 5}$ percent change in beverage processing firms in Kenya and therefore, training practice has influence on employee retention in beverage processing firms in Kenya.

Further test on ANOVA showed that the significance of the F-statistic (152.5) is less than 0.05 since $p$ value, $p=0.00$, as indicated in table below. This implied that there is a positive significant relationship between training practice and employee retention in beverage processing firms in Kenya. 
INTERNATIONAL JOURNAL OF ACADEMIC RESEARCH IN BUSINESS AND SOCIAL SCIENCES

Vol. 9, No. 7, July, 2019, E-ISSN: 2222-6990 @ 2019 HRMARS

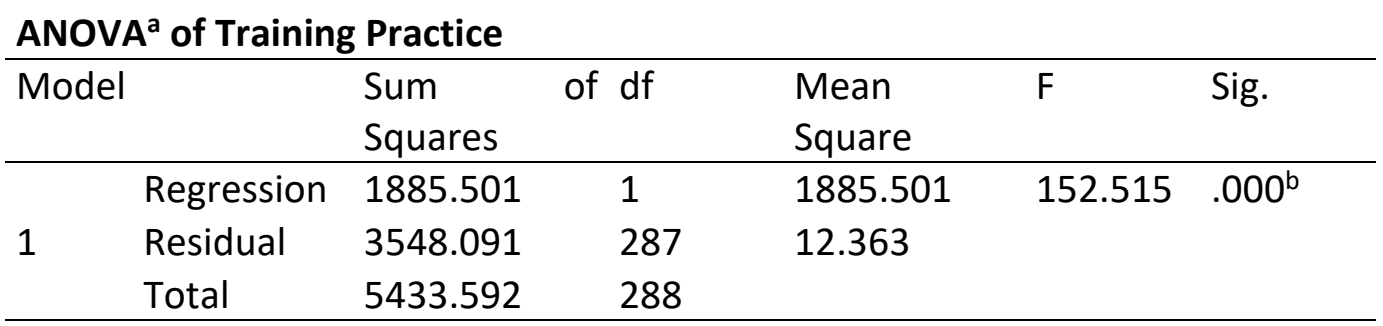

a. Dependent Variable: Retention

b. Predictors: (Constant), Training

Additional test on the beta coefficients of the resulting model, showed that the constant $\beta=3.732$ if the independent variable of training practice is held constant then there will be a positive on employees retention in beverage processing firms in Kenya by 3.732. The regression coefficient for training practice was positive and significant $(\beta=0.571)$ with a $\mathrm{t}$-value $=12.35$ ( $p$-value $<0.001)$ implying that for every 1 unit increase in training practice, employees retention in beverage processing firms in Kenya is predicted to increase by 0.571 units and therefore hypothesis was rejected. As shown in Table below.

\begin{tabular}{llllll}
\multicolumn{2}{l}{ Coefficients $^{\mathrm{a}}$ of Training Practice } & & \\
\hline Model & $\begin{array}{l}\text { Unstandardized } \\
\text { Coefficients }\end{array}$ & $\begin{array}{l}\text { Standardized } \\
\text { Coefficients }\end{array}$ & $\mathrm{t}$ & Sig. \\
& $\mathrm{B}$ & Std. Error & Beta & \\
\hline (Constant) & 3.732 & .803 & & 4.650 & .000 \\
Training & .571 & .046 & .589 & 12.350 & .000 \\
\hline
\end{tabular}

\section{a. Dependent Variable: Retention}

From the results it is revealed that training significantly influence employees' retention in beverage processing firms in Kenya. This finding is in harmony with Cole (2005) who observed that training practices in organizations should be guided by polices which should be adhered to always. Training is beneficial to the organization as well to the individual. With a well trained workforce, the organization will turn out a high standard of goods or services, probably in more cost-effective manner than others, and therefore, with a better chance of achieving organizational goals are they profit oriented or service oriented. Other benefits to the organization include maintenance of a sufficient and suitable range of skills amongst employees; development of knowledge and skills in the workforce; achievement of improved job performance and productivity; improved quality; improved service to customers and increased motivation among employees. There are also benefits to individuals which include increase in personal repertoire of skills; increased satisfaction; increased value of employees in the labour market and improved prospects of internal promotion.

\section{Conclusion and Recommendations}

Based on the study findings, it could be concluded that beverage processing firms train their employees. Further, it could be concluded that training practices in beverage processing firms are guided by polices which adhered to always. Also, it could be concluded that the implementation of training policy in beverage processing firms was done in fairly manner. Nevertheless, it could be 
concluded that some employees are not satisfied with the training practice in beverage processing firms. This might have been as a result of not involving employees in participation directly to allow them identify areas to be trained. Lastly, the study concludes that training practice showed a positive correlation with retention of employees in beverage processing firms. This implied that training practice influence positively employees retention in beverage processing firms in Kenya and therefore the hypothesis was rejected.

On training practice, the study established that beverage processing firms train their employees and training activities are guided by policy laid down in beverage processing firms. Nevertheless, from the study it was found out that some employees are not satisfied with the training practice in beverage processing firms. Therefore, the study recommends that beverage processing firms should involve employees to participate in decision making in order to allow them identify areas they need to be trained.

\section{References}

Ahmad, K. Z., and Bakar, R. A. (2003) The association between training and organizational commitment among white collar workers in Malaysia. International Journal of training and development 7(3).

Armstrong, M. A. (2010) Handbook of Human Resource Management Practice. London: Kogan Page Limited.

Armstrong, M. A., (2009) Handbook of Human Resource Management Practice London: Kogan Page Limited.

Ayodo, I. A., Namusonge, G. S., Ayodo, K. \& Maluti, V. (2014) Influence of Training on Employee Retention in Public Universities in Kenya: Case of the University Of Science and TechnologyKenya International Journal for Management Science and Technology, 2(4).

Babin, B. J., and Boles, J. S. (1996) "The effects of perceived co-worker involvement and

supervisor support on service provider role stress, performance and job satisfaction", Journal of Retailing, Vol. 72 No. 1, pp. 57-75.

Barringer, B. R., Jones, F. Neubaum, D. (2005) A quantitative Content Analysis of the characteristics of rapid growth firms and their Founders.Journal of business ventures vol. 2 No. 3

Bashir, S., Tirmizi, S. R., Noor, A., \&Shoaib, M. (2009) Determinants of Employee Retention in

Telecom Sector of Pakistan

Beardwell J., \&Claydon, T. (2007) Human Resource Management: A contemporary Approach London: Prentice Hall

Benson, G. S. (2006) Employee development, commitment and intention to turnover: a test of 'employability' policies in action. Human Resource Management Journal, 16: 173-192.

Boachie-Mensah F, Dogbe O. (2011) Performance-Based pay as a motivational tool for achieving organisational performance: an exploratory case study. International Journal for business management

Bohlander, G. W., \& Snell, S. (2007) “Managing Human Resources” (14th ed.). Cengage Learning. New York.

Branham, L. (2001). Keeping the People who keep you in Business: 24 Ways to Hang on your most Valuable Talent. New York: Amacom. 
INTERNATIONAL JOURNAL OF ACADEMIC RESEARCH IN BUSINESS AND SOCIAL SCIENCES

Vol. 9, No. 7, July, 2019, E-ISSN: 2222-6990 @ 2019 HRMARS

Bratton, J. and Gold, J. (2001) Human Resource Management Theory and Practice. Hound Mills, Palgrave Macmillan.

Bratton, J., \& Gold, J. (2009) Human resource management: theory and practice. (3rd ed.), Hampshire: Palgrave Macmillan

Cardy, R. L., and Selvarajan T. T. (2004) Assessing ethical behaviour: Development of behaviourally anchored rating scale, Proceeding of Southern Academy Management Meeting Chacha, N. C. (2004) Reforming Higher Education in Kenya: Challenges, Lessons and Opportunities. State University of New York Workshop with the Parliamentary Committee on Education, Science and TechnologyNaivasha Kenya

Chen, H. M., \& Min K. J (2004) The role of human capital cost in accounting Journal of Intellectual capital, 5(1):116-131.

Chew, J. C. (2004) The Influence of Human Resource Management Practices on Retention of Core Employees of Australian Organizations Ph.D. Thesis, Murdoch University

Chiboiwa, W. M., Samuel, M. O., \&Chipunza J. (2010) An Examination of Employee Retention

Strategy in a Private Organisation in Zimbabwe: African Journal of Business Management, 4 (10), 2103- 2109.

Chimpunza, Samuel, C. O. (2009) Employees' Retention and Turnover: using Motivational variables as panacea African Journal of Business Management Vol 3(8).

Coens T, \& Jenkins M, (2002) Abolishing performance appraisal: Why they backfire and what to do instead. Berrett-Koekler, San Francisco, C. A. USA.

Cole, G. T., (2005) Organisational Behaviour: Theory and Practice. UK: Thomson Learning.

Collins, D. (1998) Organizational Change: Sociological Perspectives, USA: Routledge.

Daly, C. J., \& Dee, J. R. (2006) Greener Pastures: Faculty Turnover Intent in Urban Public Universities. Journal of Higher Education, 77.5 (8/9), 59-64.

Dibble, S. (1999) Keeping your Valuable Employees: Retention Strategies for your Organisation. Canada: John Wiley \& Sons, Inc.

Dockel, A. (2003) The Effect of Retention Factors on Organisational Commitment: An Investigation of High Technology Employees. Master of Human Resource Thesis.University of Pretoria.

Erdogan B. (2002) Antecedents and consequences of justice perception in performance appraisals. Hum. Resource Management Rev. 12(4): 555-578.

Gerhart, B. (2005) "Human resources and business performance: findings, unanswered questions, and an alternative approach", Management Review, Vol. 16 No. 2, pp. 174-186.

Gordon, G. G. (1965) The relationship of satisfiers and dissatisfiers to productivity, turnover and morale, American Psychologist. 20, 499-502

Government of Kenya (GoK), (2006) Transformation of Higher Education and Training in Kenya: Report of the Public Universities Inspection Board. Nairobi: Government Printers.

Government of Kenya (GoK), (2007). Code of Regulations for Civil Servants Kenya: Nairobi. Government Printers.

Greenberg, J., and Baron, R. A. ( 2003) Behavior in Organizations: Understanding and Managing the Human Side of Work. Englewood Cliffs, NJ: Prentice

Gruman \& Saks., (2011) Performance management and employee engagement. Human Resource Management Review 21 123-136 
INTERNATIONAL JOURNAL OF ACADEMIC RESEARCH IN BUSINESS AND SOCIAL SCIENCES

Vol. 9, No. 7, July, 2019, E-ISSN: 2222-6990 @ 2019 HRMARS

Guma, P. V. (2011) Organisational Factors Impacting on Employee Retention. Master of Business Administration Thesis, Nelson Mandela Metropolitan University

Hamidi, Y. (2010) The effect of performance appraisal result on personnel's motivation and job promotion. Australian Journal of Basic and Applied Sciences 4(9): p. 4178-4183.

Harting, D. (2008) Employees -Your Most Valuable Asset.http://ezinearticles.com/expert Dennis_Harting, accessed on 25 July, 2011.

Holtom, B. C., Mitchell, T. R., Lee, T. W., \&Inderrieden, E. J. (2005) Shocks as Causes of Turnover: What they are and How Organizations can Manage them.

Horsoo, S. K., (2010) Employee Performance Appraisal, Rewards and Recognitions A Case Study of Barclays Bank of Ghana Limited, Kumasi, Institute of Distance Learning, KNUST.

Hughes, J. C. (2008) Talent Management; A Strategy for Improving Employee Recruitment, Retention and Management within Hospitality Organisations. Journal of Contemporary Hospitality Management Education 20 (7), 743-757

Huselid, M.A. (1995) "The impact of human resource management practices on turnover, productivity and corporate financial performance", Academy of Management Journal, Vol. 38 No. 3, pp. 635-672.

International Labour Conference, 97th Session, (2008) Skills for improved productivity, employment growth and development. International Labour Office,

Johnshrud, L., \& Rosser, J. (2002) Faculty Members' Morale and their Intention to Leave: Multilevel Explanation. Journal of Higher Education, 73 (4), 518 - 542.

Kamoche, K. N., Nyambegera, S.M., \&Mulinge, M. M. (2004) Managing Human Resources in Africa London: Routledge.

Karia, N., \&Asaari, M. H. A. (2006).The effects of total quality management practices on employees' work related attitudes. TheTQMMagazine,18(1),30-43.

Khan, M. A. (2010).Effects of human resource management practices on organizational performance an empirical study of oil and gas industry in Pakistan. European Journal of Economics, Finance and Administrative Sciences, 24, 158-175.

Kipkebut, D. J. (2010) Organisational Commitment and Job Satisfaction in Higher Educational Institutions: The Kenyan Case. PhD thesis, Middlesex University.

Korsgaard, M. A., Roberson, L. and Klein, D. A. (1991), "The effect of self-appraisal and participation on subsequent performance", Paper presented at the Society for Industrial and Organizational Psychology Conference, 1991.

Kochachathu, P. (2010) Influence of Human Resource Practices on Employee Retention Master's Thesis, University of Malaysia.

Kothari, C. R. (2009). Research Methodology: Methods and Techniques. New Delhi: New Age International Publishers.

Kuvaas, B. (2006) "Performance appraisal satisfaction and employee outcomes: mediatingand moderating roles of work motivation", International Journal of Human Resource Management, Vol. 17 No. 3, pp. 504-522.

Law, D. R. (2007). Appraising performance appraisals: A critical look at external control techniques. Intl. J. Reality Therapy, 16(2): 18-25 
INTERNATIONAL JOURNAL OF ACADEMIC RESEARCH IN BUSINESS AND SOCIAL SCIENCES

Vol. 9, No. 7, July, 2019, E-ISSN: 2222-6990 @ 2019 HRMARS

Lewa, P. (2009) Talent Management Strategies for Increased Competitiveness. United States International University (USIU-Kenya) Colloquium, 20th May, 2009.

Lepilale, J. (2009) The relationship between employee retention management practices and voluntary labour turnover in Five Star Hotels in Nairobi. University of Nairobi

Lepper, M. R., \& Malone, T. W. (1987) Intrinsic motivation and instructional effectiveness in computer-based education.

Lowenberg, G. and Conrad, K. A. (1998) Current Perspectives in Industrial/Organizational Psychology. Boston, MA: Allyn\& Bacon.

LyriaR, K., Namusonge, G. S., \& Karanja, K. (2014) Effect of Talent Retention On Organisation Performance In Companies Listed In Nairobi Securities Exchange In Kenya. European Journal of Business and Social Sciences 3(1), 47-58

Maslow, A. H. (1954) Motivation and Personality: NY: Harper.

Mathis, R. L., \& Jackson, J. H. (2005) Human Resources Management (3rd ed.). Thompson, Bangalore.

McKeown, E. (2010) Retention in the Upswing. Training and Development, 22.McKeown, J. L. (2002). Retaining Top Employees New York: McGraw-Hill.

McNamara, C. (2005). Human Resource Management and Talent Management Authenticity Consulting LLC.

Metcalf, H., Rolfe P., \& Weale. M. (2005) Recruitment and Retention of Academic Staff in Higher Education.National Institute of Economic and Social Research, Research Report RR 658.

Mtazu, S. P. (2009) Evaluating Remuneration and Reward Systems at Lobels Bread.Master of Business Administration Thesis, Nelson Mandela Metropolitan University's Business School

Michael, S. O. (2008) Using Motivational Strategy as Panacea for Employee Retention and Turnover in Selected Public and Private Sector Organisations in the Eastern Cape Province of South Africa. Master of Commerce Thesis, University of Fort Hare.

Mondy, R. (2008) Human Resource Management 10th ed., New Jersey: Prentice Hall.

Moon, C., Lee, J., Jeong, C., Lee, J., Park, S. \& Lim, S. (2007). An Implementation Case for the Performance Appraisal and Promotion Ranking, in IEEE International Conference on System, Man and Cybernetics, 2007.

Muceke, E. I., \& Namusonge, G. S. (2012) Determinants of Academic Staff Retention in Public Universities in Kenya: Empirical Review. International Journal of Humanities and Social Science Vol. 2 No. 13; July 2012

Mugenda and Mugenda (2008) Research Methods (3rdedition) Jomo Kenyatta Publishers.Nairobi.Kenya

Mulvaney, M. A., McKinney, W. R., \& Grodsky, R. (2008) The development of a pay-for-performance appraisal system for public park and recreation agencies: A case study. J. Park and Recreation Admin., 26(4):126156.

Munsamy, M., \& Venter, B. A. (2009) Retention Factors of Management Staff in the Maintenance Phase of their Careers in Local Government. SA Journal of Human Resource Management, 7 (1), 187-195.

Nambuswa E, J. M., Namusonge, G. S. \& Kinali. (2014) Determinants of Effectiveness of Employee Performance Appraisal System in Institution of Higher Learning: A Survey of Public 
INTERNATIONAL JOURNAL OF ACADEMIC RESEARCH IN BUSINESS AND SOCIAL SCIENCES

Vol. 9, No. 7, July, 2019, E-ISSN: 2222-6990 @ 2019 HRMARS

Universities in Nakuru County. European Journal of Business and Management Vol.6No.8, 2014

Namusonge, G. S., Karanja, K, \&Mutua, S. M. (2012) 'Role of Human Resource Management Practices on Performance of Financial Cooperatives Based in Nairobi County, Kenya' International Journal of Humanities and Social Science, Vol. 2 No. 22, pp.289-297.

Newman, A., Thanacoody, R., \& Hui., W. (2010) The Impact of Employee Perceptions of Training on Organisational Commitment and Turnover Intentions: A Study of Multinationals in the Chinese Service Sector

Ng'ethe, J. M., Iravo, M. E., \& Namusonge, G. S. (2012) Determinants of academic staff retention in Public universities in Kenya: Empirical review International Journal of Humanities and Social Science, 2(13), 205212.

Nzuve, S. N. M. (2007) Management of human resources; a Kenyan perspective, Nairobi, basic modern management consultants

Obwogi, J. (2011) Factors that Affect Quality of Teaching Staff in Universities in Kenya PhD Thesis. Jomo Kenyatta University of Agriculture and Technology

Orodho, C. R. (2003) Elements of Education and Social Science Research Methods (2 ${ }^{\text {nd }}$ Edition)

Kanezja Publishers New Delhi India

Pettijohn, C. E., Pettijohn, L. S., Taylor, A. J., and Keillor, B. D. (2001) "Are performance appraisals a bureaucratic exercise or can they be used to enhance sales-force satisfaction and commitment?" Psychology \& Marketing, Vol. 18 No. 4, pp. 337-364.

Phillips, J., \& Connell, O. (2003) Managing Employee Retention: A Strategic Accountability Approach USA: Heinemann.

Pienaar, C., \& Bester, C. L. (2008) Retention of Academics in the Early Career Phase. SA Journal of Human Resource Management, 6 (2), 32 - 41.

Price, J. (2001) Reflections on the Determinants of Voluntary Turnover: International Journal of Manpower, 22 (7), 600-624.

Pienaar, C., \& Bester, C. L. (2008) Retention of Academics in the Early Career Phase. SA Journal of Human Resource Management, 6 (2), 32 - 41.

Radivoev, J. (2005) The Retention of Sales Consultants in the Security Industry Master of Business Management Thesis University of Johannesburg

Rana, T. M., Salaria, M. R., Herani, G. M., \& Amin, M. A. (2009) Identifying Factors Playing Important Role in the Increasing Employee Industrial Journal of Management and Social Sciences 2 (3).

Rezghi R. T. (2000) Performance evaluation system, Tadbir Publication, No, 114.

Robbins, P. and Judge, A. (2009) Organizational Behavior. New Jersey: Pearson Education, Inc

Romano, S., Chege, K., Mutua, S., \& Musiega, D. (2014) Effects of Employee Engagement on Employee Retention in Micro-Finance Institutions. The International Journal of Business \& Management (ISSN 2321 - 8916).

Rosser, V., (2004) Faculty Members' Intention to leave.A national Study on their Work-life and Satisfaction. Research in Higher Education, 45 (3), 285 -309.

Samganakkan, S. (2010) mediating role of organizational commitment on HR practices and turnover intention among ICT professional, Management research 
INTERNATIONAL JOURNAL OF ACADEMIC RESEARCH IN BUSINESS AND SOCIAL SCIENCES

Vol. 9, No. 7, July, 2019, E-ISSN: 2222-6990 @ 2019 HRMARS

Sanderson, A., Phua, V. \& Herda, D. (2000) The American Faculty Poll. TIAA-CREF, New York: National Opinion Research Center, Illinois: Chicago.

Shoaib, M., Noor, A., Tirmizi, S., \& Bashir, S. (2009) Determinants of Employee Retentionin Telecom Sector of Pakistan. Proceedings 2nd CBRC, Lahore, Pakistan, 14th November, 2009.

Smither, R. D. (1998) The Psychology of Work and Human Performance (3 ${ }^{\text {rd }}$ ed.). NewYork: Longman.

Soh, K. B. K. (1998) Job analysis, appraisal and performance assessments of a surgeon a multifaceted approach. Singapore Med J., 39(4):180- 185. PMID: 9676152

Sutherland, M. M., (2004) Factors Affecting the Retention of Knowledge Workers. Published PhD Thesis, Rand Afrikaans University

Ssesanga, K, \& Garrett, R. M. (2005) Job satisfaction of University Academics: Perspectives from Uganda. Higher Education, 50, 33-56.

Stavrou-Costea, E. (2005) Flexible Work Bundles and Organisational Competitiveness in Europe: Toward a Framework. Journal of Organisational Behaviour, 26

Storey, J. (1992) Developments in the Management of Human Resources. Oxford: Blackwell.

Terrence H. M., \& Joyce M., (2004) Performance appraisals: ABA labour and employment law section, equal opportunity committee.

Tettey, J. W. (2006). Staff Retention in African Universities: Elements of a Sustainable strategy, Washington, DC: World Bank.

Udi, G. (2010) Determinants of Staff Retention in Service Organisations: A Case of Consumer Insight Ltd. Master's Thesis, Jomo Kenyatta University of Agriculture and Technology.

Waleed, A., (2011) The Relationship between Human Resource Practices and Employee Retention in Public Organisations: An Exploratory Study Conducted in the United Arab Emirates. PhD Thesis, Edith Cowan University.

Wangui, A. (2009) Employee retention in local Kenyan banks; A case study of Equity bank Strathmore Business School, MBA Thesis.

Wanjiru, S. (2007) Factors that influence employee retention in manufacturing firms in Nairobi University of Nairobi MBA Thesis.

Waswa, F., \& Katana, G. (2008) Academic Staff Perspectives on Operating Beyond Industrial Actions for Sustainable Quality Assurance in Public Universities in Kenya.International Journal of

Environment, 4(1), 45-58.

Yee, C. C, \& Chen, Y. Y., (2009) Performance appraisal system using multifactorial evaluation model.PWASET, 41: 231-235

Yousaf, A. (2010) One Step Ahead: Examining New Predictors of Affective and Organisational Occupational Commitment. PhD Thesis, University of Twent 